\title{
Histopathological aspects of the liver of free-living and farmed bullfrogs (Lithobates catesbeianus)
}

\section{José Teixeira de Seixas Filho ${ }^{1,6^{*}}$, Claudio Barberini Camargo Filho' ${ }^{2}$, Marcelo Maia Pereira1, Ana Maria Cristina Rebello Pinto da Fonseca Martins ${ }^{3}$, Oswaldo Pinto Ribeiro Filho ${ }^{4}$, Sílvia Conceição Reis Pereira Mello ${ }^{1,6}$, Luara Lucena Cassiano ${ }^{5}$, Marcio Hipolito ${ }^{3}$}

\author{
${ }^{1}$ Fundação Instituto de Pesca do Estado do Rio de Janeiro, Rio de Janeiro, RJ, Brazil. \\ ${ }^{2}$ Instituto Federal do Espírito Santo, Alegre, ES, Brazil. \\ ${ }^{3}$ Instituto Biológico, Laboratório Interinstitucional em Sanidade em Aquicultura, São Paulo, SP, Brazil. \\ ${ }^{4}$ Universidade Federal de Viçosa, Departamento de Biologia Animal, Viçosa, MG, Brazil. \\ ${ }^{5}$ Instituto Biológico, Programa de Pós-graduação em Sanidade, Segurança Alimentar e Ambiental no Agronegócio, São Paulo, SP, Brazil. \\ ${ }^{6}$ Centro Universitário Augusto Motta, Programa de Pós-graduação em Desenvolvimento Local, Rio de Janeiro, RJ, Brazil.
}

\begin{abstract}
The objective of this study was to compare the histopathological aspects of the liver of free-living and farmed bullfrogs (Lithobates catesbeianus). Thirty liver samples were collected from young and adult bullfrogs in the states of Minas Gerais and Rio de Janeiro, Brazil. Marked blood congestion and even hemorrhage and a large number of melanomacrophages were observed in most of the livers from free-living bullfrogs. Additionally, hepatocytes showed cytoplasmic eosinophilia and some showed nuclear hypertrophy and presence of microvesicular steatosis; small foci of infiltrates of mononuclear cells were observed in some samples, as well as a thicker capsule. In the farmed bullfrogs, cytoplasmic rarefaction was normal. Morphologically, unlike the livers of animals reared on farms, the livers of free-living animals did not show any evidence of protein-mineral deficiency, characterized by cytoplasmic vacuolation and a larger number of melanomacrophages, suggesting greater aggression to the liver parenchyma, probably due to environmental toxicity. Free-living bullfrogs feed on proteins of better biological value, derived from animals preyed in the natural environment.
\end{abstract}

Key Words: amphibians, diet, nutritional disorder, pathology, protein

\section{Introduction}

The bullfrog (Lithobates catesbeianus) was introduced in Brazil in the 1930s as a farming alternative because of its easy adaptation to the climate conditions of Brazil. Since then, its production rapidly spread across the country (Cunha and Delariva, 2009). Despite government requirements for the construction of barriers to prevent the escape of bullfrogs, some of these animals escaped and currently live free in the wild in several Brazilian states (Ferreira and Lima, 2012) and in other South American countries (Akmentis and Cardozo, 2010).

Received: November 3, 2015

Accepted: January 9, 2017

*Corresponding author: seixasfilho@yahoo.com.br

http://dx.doi.org/10.1590/S1806-92902017000400001

How to cite: Seixas Filho, J. T.; Camargo Filho, C. B.; Pereira, M. M.; Martins, A. M. C. R. P. F.; Ribeiro Filho, O. P.; Mello, S. C. R. P.; Cassiano, L. L. and Hipolito, M. 2017. Histopathological aspects of the liver of free-living and farmed bullfrogs (Lithobates catesbeianus). Revista Brasileira de Zootecnia 46(4):275-279

Copyright (C) 2017 Sociedade Brasileira de Zootecnia. This is an Open Access article distributed under the terms of the Creative Commons Attribution License (http://creativecommons.org/licenses/by/4.0/), which permits unrestricted use, distribution, and reproduction in any medium, provided the original work is properly cited.
The diet of free-living bullfrogs is based on invertebrates and small vertebrates (Hirai, 2004; Silva et al., 2009; Leivas et al., 2012). By contrast, captivity-reared bullfrogs consume balanced diets containing ingredients of animal and plant origins (Olvera-Novoa et al., 2007; Rodrigues et al., 2007; Castro et al., 2008). Of the commercial diets, those that provide the best performance have a crude protein content higher than 40\% (Casali et al., 2005; Fenerick Jr. and Stéfani, 2005). However, the use of these commercial diets has caused some alterations in organs like the liver, which may compromise the animal performance (Seixas Filho et al., 2009; Seixas Filho et al., 2013).

The liver plays a number of indispensible functions in many body physiological processes, particularly those related to the metabolism, such as the synthesis of proteins and metabolites, storage of vitamins, glucose release, transformation of carbohydrates and protein into lipids by deamination of amino acids to be used or transformed in carbohydrates and lipids, in addition to detoxification (Abbas et al., 2010; Akiyoshi and Inoue, 2012).

Unfortunately, knowledge of the normal and abnormal functions of the liver of amphibians is still limited (Seixas Filho et al., 2008a,b). There are no clinical procedures or tools for a precise diagnosis or acceptable prognosis. 
Therefore, most of the liver disorders are only known through a retrospective diagnosis or by necropsy (Crawshaw and Weinkle, 2000).

The objective of this study was to make a histological comparison between the liver of free-living bullfrogs captured near commercial frog farms and the liver of commercially farmed animals, aiming to provide foundations for nutritionists in their choice of the ingredients for the preparation of appropriate diets to reduce mortality and improve the performance of farmed animals.

\section{Material and Methods}

Ten specimens of free-living adult bullfrogs (Lithobates catesbeianus), with average weight of $420 \pm 52 \mathrm{~g}$, were collected in the proximity of commercial frog farms in the cities of Viçosa and Ponte Nova, MG, Brazil, and other 10 adults and 10 juvenile bullfrogs, with initial average weight of, respectively, $360 \pm 35$ and $25 \pm 8.6 \mathrm{~g}$, were sampled near an experimental frog farm in Rio de Janeiro, RJ, Brazil.

For comparison purposes, adult and juvenile bullfrogs from a flooded rearing system, used in commercial farming, were also collected. In this rearing system, the juveniles had access to a diet containing $45 \%$ crude protein, while the adults received a diet with $40 \%$ crude protein. These commercial diets had animal and plant-derived ingredients, as stated in the informative label that follows the standards of the Brazilian Ministry of Agriculture.

After capturing the free-living and farmed animals, they were anesthetized with benzocaine and sacrificed by a spinal-cord section, as recommended by IACUC (2007).

After the above-mentioned step, frogs were placed in dorsal decubitus position and a posteroanterior ventral incision was made using surgical scissors with a fine tip to expose the viscera. The liver was separated with tweezers and care was taken to isolate, but not deform, the organ.

The collected livers were fixed in $10 \%$ calcium carbonate buffered formalin. For the histology procedure, the livers were dried, diaphonized, paraffin-embedded, cut into 5- $\mu \mathrm{m}$ thick sections, stained with hematoxylin (Harris)eosin, and observed under a common light microscope by direct transillumination (Seixas Filho et al., 2013).

\section{Results}

Necropsy revealed that most livers from free-living frogs had normal color, size, and consistency, as well as anatomical appearance and limiting borders. However, irregular borders were noted in some specimens.
Histological analysis of the livers of bullfrogs showed the presence of many melanomacrophages, hepatocytes with eosinophilic cytoplasm, and some with highly enlarged nuclei intermingled with normal hepatocytes with clearer cytoplasm and round, typical nuclei (Figure 1). Small foci of hepatitis with mononuclear inflammatory cells were also observed (Figure 2).

Congested vessels and sinusoids, hemorrhage, melanomacrophages, and wavy borders were observed in some animals (Figure 3). It should be stressed that the cytoplasm of the hepatocytes was eosinophilic,

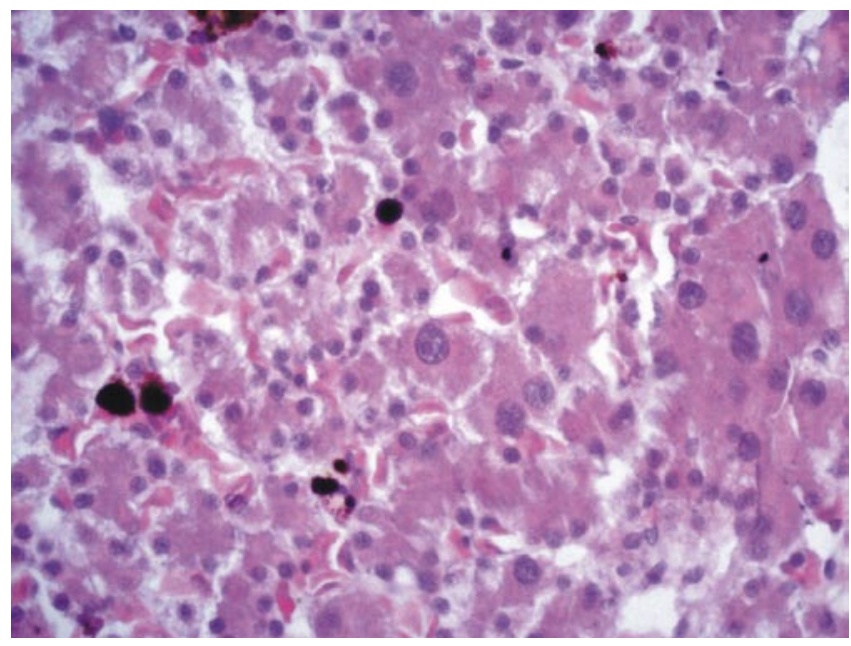

Note, in the center, a largely increased cell nucleus and surrounded by normal, smaller nuclei.

Hematoxylin-eosin staining, 400X.

Figure 1 - Photomicrograph of the liver of a free-living bullfrog with liver parenchyma with eosinophilic hepatocytes.

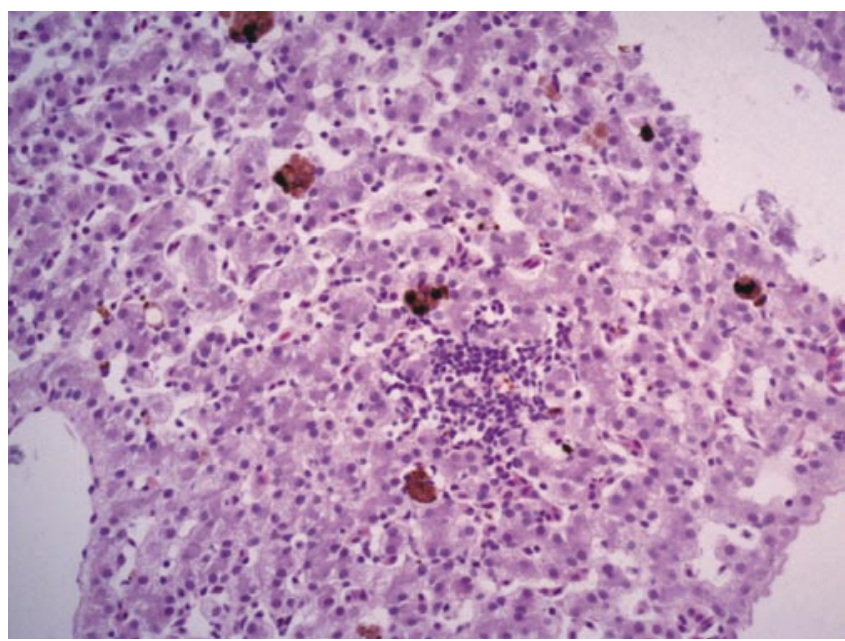

Hematoxylin-eosin staining, 200X.

Figure 2 - Photomicrograph of the liver of a free-living bullfrog with focus of mono-lymphocytic hepatitis. 
with absence of hydropic rarefaction or regeneration, appearing to be a normal parenchyma (Figure 4). Presence of microgoticular steatosis was also detected in several specimens (Figure 5).

The presence of a parasite surrounded by melanomacrophages and with a thicker liver capsule was noted in one of these free-living specimens (Figure 6).

Contrasting these findings, the livers of farmed bullfrogs showed a different color, from whitish to dark, in addition to hydropic degeneration and rarefaction of the cytoplasm of hepatocytes, with a cytoplasmic transparency (Figure 7).

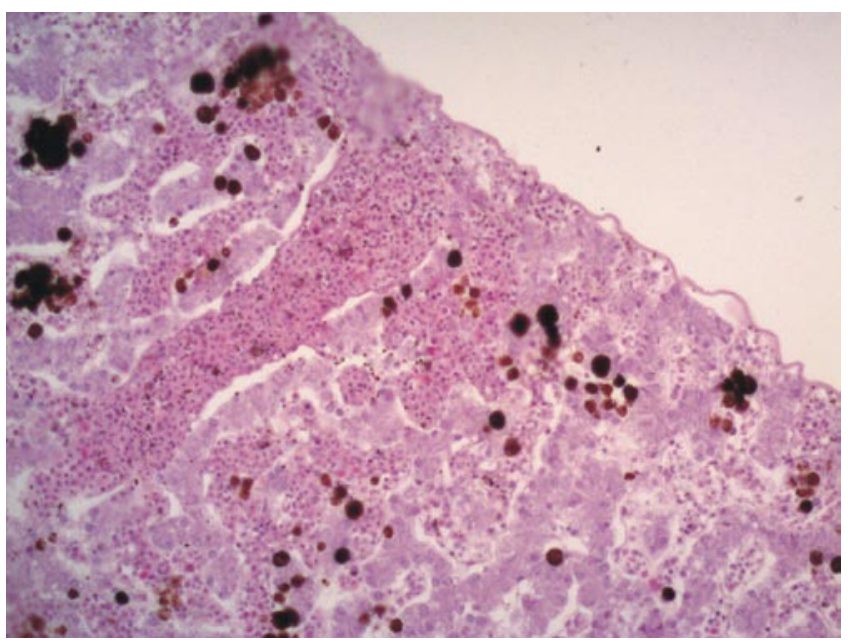

Hematoxylin-eosin staining, 200X.

Figure 3 - Photomicrograph of the liver of a free-living bullfrog with congestion of blood vessel and sinusoids, melanomacrophages, and wavy border.

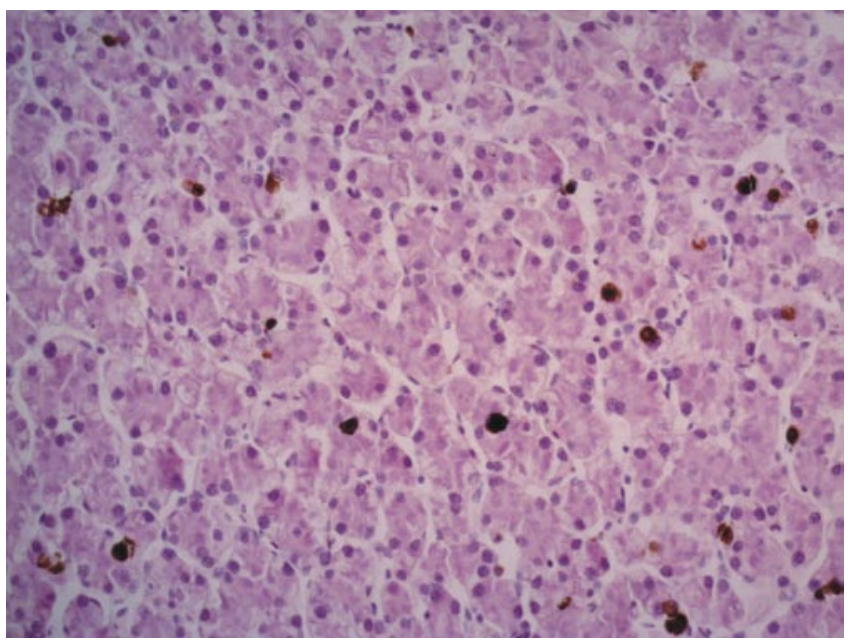

Hematoxylin-eosin staining, 200X.

Figure 4 - Photomicrograph of the liver of a free-living bullfrog with normal liver parenchyma.

\section{Discussion}

Within this histopathology case, what drew attention to the free-living animals was the presence of a denser cytoplasm of hepatocytes and, therefore, the nonobservation of protein-mineral deficiency when compared with the hepatocytes of captive animals, which were characterized by a lack of content or rarefaction of the cytoplasmic contents of these cells.

Even in seemingly healthy animals, resulting from commercial farming, with a normal liver aspect, this cytoplasmic rarefaction is always present and with alterations in the liver biochemical profile (Hipolito, 2003; Hipolito et al., 2004; 2007).

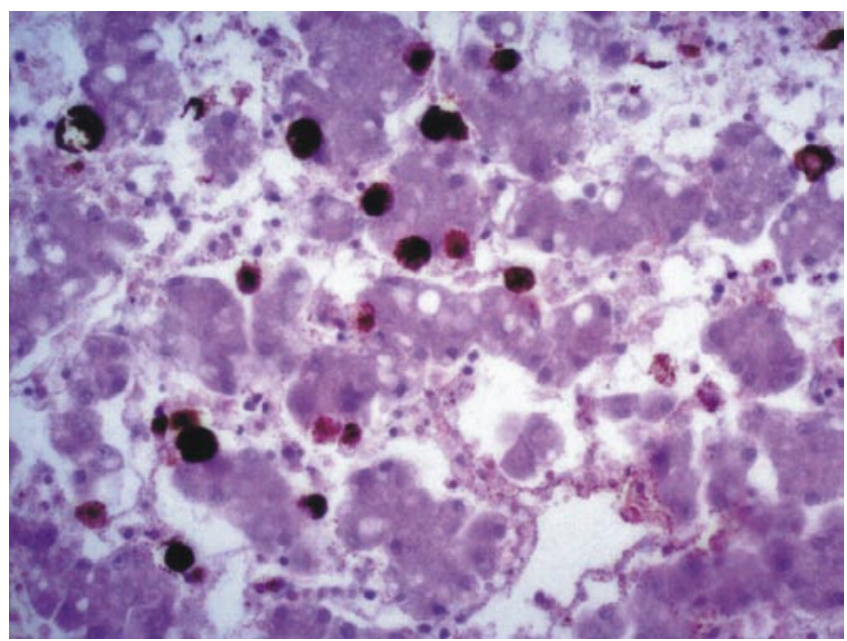

Hematoxylin-eosin staining, 400X.

Figure 5 - Photomicrograph of the liver of a young free-living bullfrog with microgoticular steatosis.

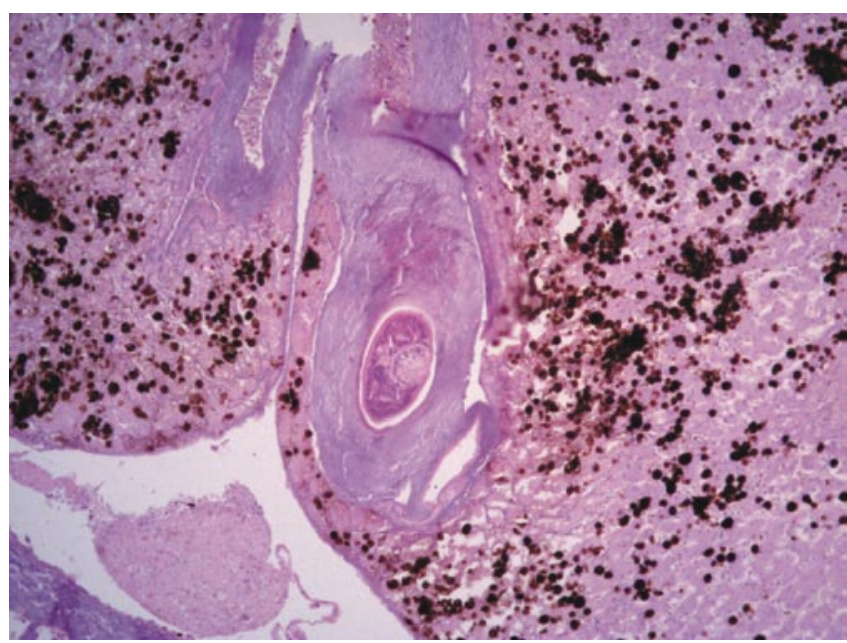

Hematoxylin-eosin staining, 100X.

Figure 6 - Photomicrograph of the liver of a young free-living bullfrog with thickened liver cell, high number of melanomacrophages, and presence of parasite. 


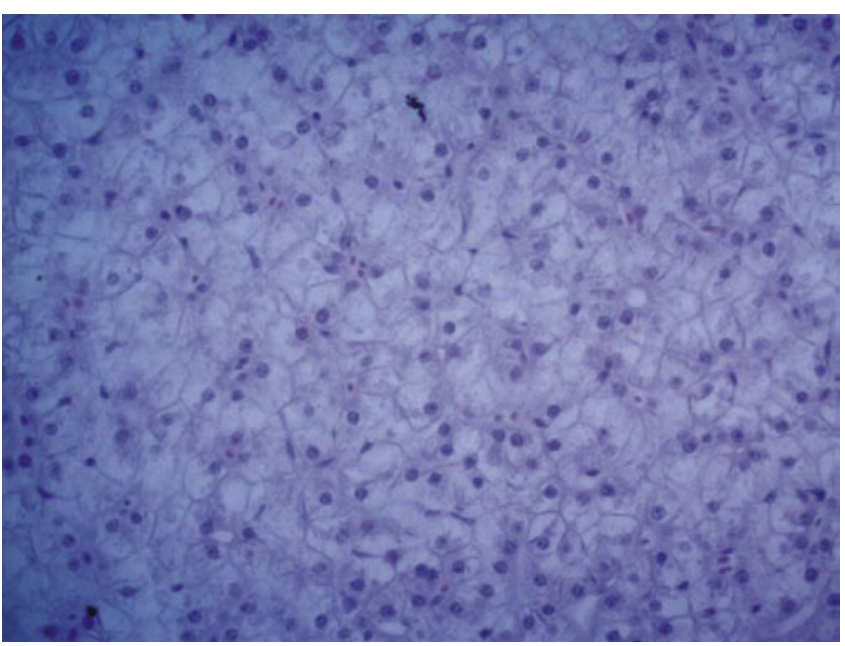

Hematoxylin-eosin staining, 400X.

Figure 7 - Photomicrograph of the liver of an adult farmed bullfrog with marked rarefaction of the cytoplasm of hepatocytes.

Hydropic degeneration is the first manifestation of nearly all forms of cellular damage and it occurs due to the inability of the cell to maintain the ionic balance, caused by a failure in the energy-dependent pumps of cell membranes. Consequently, the homeostasis of fluids is compromised (Abbas et al., 2010).

This hydropic degeneration/cytoplasmic rarefaction is extremely common, to a greater or lesser degree, when we observe histologically the liver of frog raised on farms, fed commercial diets, even with high levels of crude protein in these feeds. This has already been noted for some time and occurring at all rearing stages from tadpoles to adults (Seixas Filho et al., 2008 a,b; 2009; 2013). This degeneration was also reported by Freitas et al. (2014), in an experiment with bullfrogs fed diets containing $45 \%$ crude protein and supplemented with a probiotic (Bacillus subtilis) and betaglucan in $100 \%$ of samples.

Because free-living bullfrogs feed only by preying on insects, other invertebrates, and small vertebrates and its animal protein intake is consequently low (Hirai, 2004; Silva et al., 2009; Leivas et al., 2012), this protein-mineral deficiency is practically not observed.

These animal proteins suggest that they are more appropriate for the species and, thus, better used, unlike animals fed commercial products, in which most part of the crude protein derives from plants, carrying a lower biological value. These questions suggest the need for the continuity of studies on this subject.

The presence of alterations in the liver capsule, steatosis, melanomacrophages, congested vessels, infiltrates from inflammatory cells, and hemosiderotic pigments may be associated with environmental actions or several biological attacks, which usually affect free-living animals. The presence of other pigments in the liver of amphibians can be considered common (Crawshaw and Weinkle, 2000), but is more closely associated with some type of aggression to which the liver is subjected.

\section{Conclusions}

The supply of diets with protein of low biological value for bullfrogs may compromise their health and performance due to the resulting liver damage.

\section{References}

Abbas, A. K; Fausto, N.; Kumar, V.; Cotran, R. S.; Aster, J. C. and Robbins, S. L. 2010. Robbins e Cotran: Patologia - Bases patológicas das doenças. 8.ed. Elsevier, Rio de Janeiro.

Akiyoshi, H. and Inoue, A. M. 2012. Comparative histological study of hepatic architecture in the three orders amphibian livers. Comparative Hepatology 11:1-8.

Akmetins, M. S. and Cardozo, D. E. 2010. American bullfrog Lithobates catesbeianus (Shaw, 1802) invasion in Argentina. Biological Invasions 12:735-737.

Casali, A. P.; Moura, O. M. and Lima, S. L. 2005. Rações comerciais e o rendimento de carcaça e subprodutos de rã-touro. Ciência Rural 35:1172-1178.

Castro, J. C.; Barboza, W. A.; Silva, K. K. P. and Pires, S. C. 2008. Níveis de energia metabolizável para rações de rã-touro. Boletim do Instituto de Pesca 34:519-525.

Crawshaw, G. J. and Weinkle, T. K. 2000. Clinical and pathological aspects of the amphibian liver. Seminars in Avian and Exotic Pet Medicine 9:165-173.

Cunha, E. R. and Delariva, R. L. 2009. Introdução da rã-touro, Lithobates catesbeianus (Shaw, 1802): uma revisão. SaBios: Revista de Saúde e Biologia 4:34-46.

Fenerick Jr, J. and Stéfani, M. V. 2005. Desempenho e parâmetros metabólicos de rã touro, Rana catesbeiana, alimentada com diferentes rações comerciais. Acta Scientiarium. Animal Science 27:377-383.

Ferreira, R. B. and Lima, C. S. 2012. Anuran hotspot at Brazilian Atlantic rainforest invaded by the non-native Lithobates catesbeianus Shaw, 1802 (Anura: Ranidae). North-Western Journal of Zoology 8:386-389.

Freitas, J. J. G.; Bach, E. E.; Bordon, I. C. A. C.; Martins, A. C. R. P. F.; Hipolito, M. and Ferreira, C. M. 2014. Resposta hepática à suplementação alimentar em rãs-touro sob condição de estresse. Boletim do Instituto de Pesca 40:261-269.

Hipolito, M. 2003. Deficiência proteica e demais patologias associadas ao fígado de rãs-touro (Rana catesbeiana SHAW, 1802). Boletim do Instituto de Pesca 34:29-33.

Hipolito, M.; Martins, A. M. C. R. P. F. and Bach, E. E. 2004. Aspectos bioquímicos em fígado de rãs-touro (Rana catesbeiana Shaw, 1802) sadias e doentes. Arquivos do Instituto Biológico 71:147-153.

Hipolito, M.; Ribeiro Filho, O. P. and Bach, E. E. 2007. Aspecto bioquímico em fígados de Rana catesbeiana (Shaw, 1802) submetida a diferentes dietas. ConScientiae Saúde 6:49-56. 
Hirai, T. 2004. Diet composition of introduced bullfrog, Rana catesbeiana, in the Mizorogaike Pond of Kyoto, Japan. Ecological Research 19:375-380.

IACUC - Institutional Animal Care and Use Committee. 2014. Fish and amphibian euthanasia (CARE 306.01) Cornell Institutional Animal Care and Use Committee and the Cornell Center for Animal Resources and Education, Cornell University, Cornell, USA.

Leivas, P. T.; Leivas, F. W. T. and Moura, M. O. 2012. Diet and trophic niche of Lithobates catesbeianus (Amphibia: Anura). Zoologia 29:405-412.

Olvera-Novoa, M. A.; Ontiveros-Escutia, V. M.; Flores-Nava, A. 2007. Optimum protein level for growth in juvenile bullfrog (Rana catesbeiana, Shaw, 1802). Aquaculture 266:191-199.

Rodrigues, M. L.; Lima, S. L.; Moura, O. M.; Agostinho, C. A.; Silva, J. H. V.; Silva, G. R. B.; Cruz, V. M.; Campos, V. M.; Casali, A. P.; Mendes, R. R. B. and Albuquerque, A. G. 2007. Efeito dos níveis de proteína e relação energia/proteína sobre o desempenho da rãtouro. Archivos de Zootecnia 56:939-942.

Seixas Filho, J. T.; Gomes, L. H.; Aguiar, D. V. C.; Hipolito, M.; Martins, A. M. C. R. P. F. and Chaves, A. C. P. 2008a. Avaliação histológica do intestino médio, do fígado e do pâncreas de girinos de rã-touro alimentados com rações comerciais formuladas com três níveis de proteína bruta. Revista Brasileira de Zootecnia 37:2090-2096

Seixas Filho, J. T.; Hipolito, M.; Carvalho, V. F.; Martins, A. M. C. R. P. F.; Silva, L. N.; Castagna, A. A. 2008b. Alterações histopatológicas em girinos de rã-touro alimentados com rações comerciais de diferentes níveis protéicos. Revista Brasileira de Zootecnia 37:2085-2089.

Seixas Filho, J. T.; Hipolito, M.; Martins, A. M. C. R. P. F.; Rodrigues, E.; Castagna, A. A. and Mello, S. C. R. P. 2009. Histopathological alterations in bullfrog juveniles fed commercial rations of different crude protein levels. Revista Brasileira de Zootecnia 38:2306-2310.

Seixas Filho, J. T.; Hipólito, M.; Pereira, M. M.; Martins, A. M. C. R. P. F.; Rodrigues, E. and Mello, S. C. R. P. 2013. Liver histopathological changes in breeding bullfrogs. Acta Scientiarium, Animal Science 35:461-465.

Silva, E. T.; Reis, E. P.; Feio, R. N. and Ribeiro Filho, O. P. 2009. Diet of the invasive frog Lithobates catesbeianus (Shaw, 1802) (Anura: Ranidae) in Viçosa, Minas Gerais State, Brazil. South American Journal of Herpetology 4:286-294. 